\title{
THE EFFECTS OF CREATINE AND RELATED COMPOUNDS ON CARDIOVASCULAR SYSTEM: FROM BASIC TO APPLIED STUDIES
}

\author{
Nevena Draginic ${ }^{1}$, Veljko Prokic ${ }^{2}$, Marijana Andjic ${ }^{1}$, Aleksandra Vranic ${ }^{1}$, Suzana Pantovic ${ }^{2}$ \\ ${ }^{1}$ University of Kragujevac, Faculty of Medical Sciences, Department of Pharmacy, Kragujevac, Serbia \\ ${ }^{2}$ University of Kragujevac, Faculty of Medical Sciences, Department of Physiology, Kragujevac, Serbia
}

\section{UTICAJI KREATINA I SRODNIH SUPSTANCI NA KARDIOVASKULARNI SISTEM: OD BAZIČNIIH DO PRIMIENJENIH STUDIJA}

\author{
Nevena Draginić1 ${ }^{\text {, Veljko Prokić }}$, Marijana Anđić ${ }^{1}$, Aleksandra Vranić1 ${ }^{\text {, Suzana Pantović }}{ }^{2}$ \\ ${ }^{1}$ Univerzitet u Kragujevcu, Fakultet medicinskih nauka, Katedra za farmaciju, Kragujevac, Srbija \\ ${ }^{2}$ Univerzitet u Kragujevcu, Fakultet medicinskih nauka, Katedra za fiziologiju, Kragujevac, Srbija
}

\begin{abstract}
Beneficial effects of creatine were firstly shown in sport, where itself has been recognized as an ergogenic substance, increasing exercise endurance, muscle strength and lean body mass. Creatine supplementation is very interesting, due to the fact that creatine supplementation have been reported to be beneficial for wide spectrum of diseases and conditions referring neurodegenerative, rheumatic diseases, myopathies, cancer, type 2 diabetes. Creatine is a principle component of the creatine kinase/phosphagen system. In cardiomyocytes, it plays an important role in the buffering and transport of chemical energy to ensure that supply meets the dynamic demands of the heart. Studies in mice proved that elevated creatine protects the heart from ischemia-reperfusion injury. A natural precursor of creatine, guanidinoacetic acid (GAA), plays an important role as an energy carrier/mediator in the cell. GAA is formed in the first step of creatine synthesis. Supplementation with GAA might be of great significance in some circumstances where biosynthesis of GAA is limited like deficient diet, kidney failure, renal insufficiency, exercise-related GAA depletion. Betaine is a neutral compound in the form of zwitterion. Betaine supplementation is associated with improved cognition, neuroprotection, cardioprotection and exercise physiology. Betaine insufficiency represents increased risk for secondary heart failure and acute myocardial infarction. This mini-review outlines the evidence in support of creatine and creatine related compounds (GAA and betaine) elevation and examines the pharmacological approaches that are currently available. Since data from the available studies, regarding cardioprotection are inconsistent, this review might help clarifying the benefits of creatine, GAA and betaine supplementation on cardiovascular system.
\end{abstract}

Keywords: betaine, creatine, guanidinoacetic acid, cardiovascular system

\section{SAŽETAK}

Pozitivni efekti kreatina pokazani su najpre u sportu, gde je prepoznat kao ergogena supstanca, povećavajući otpornost na vežbanje, snagu mišića i telesnu masu. Suplementacija kreatinom pokazala je pozitivne efekte na veliki broj bolesti i stanja kao što su neurodegenerativne, reumatske bolesti, miopatije, karcinom, dijabetes tip 2. Kreatin je glavna komponenta kreatin kinaza fosfagenog sistema. U kardiomiocitima igra važnu ulogu u transportu hemijske energije čime obezbeđuje energetske potrebe srca. Studije na miševima pokazale su da povišen nivo kreatina ima protektivni efekat na ishemijsko-reperfuzionu povredu. Prirodni prekursor kreatina, guanidinoacetatna kiselina (GAA), igra važnu ulogu kao nosilac energije/posrednik u ćeliji. GAA se formira u prvom koraku sinteze kreatina. Suplementacija GAA-om može biti od velikog značaja u nekim okolnostima kada je biosinteza GAA ograničena, poput nedovoljnog unosa ishranom, bubrežne i renalne insuficijencije i smanjenja GAA povezanog sa vežbanjem. Betain je neutralno jedinjenje u obliku cviter jona. Suplementacija betainom povezuje se sa poboljšanom kognicijom, neuroprotekcijom, kardioprotekcijom i boljim efektima fizičke aktivnosti. Nedostatak betaina predstavlja povećani rizik za sekundarnu srčanu insuficijenciju i akutni infarkt miokarda. Ovaj pregledni članak pokazuje značaj kreatina $i$ srodnih supstanci (GAA i betaina) i ispituje farmakološke pristupe koji su trenutno dostupni. S obzirom da su podaci o kardioprotektivnom efektu nekonzistentni, ovaj pregledni rad može pomoći da se razjasne prednosti suplementacije kreatina, GAA i betaina na kardiovaskularni sistem.

Ključne reči: betain, kreatin, guanidinoacetatna kiselina, kardiovaskularni sistem

\section{sciendo}

DOI: 10.2478/sjecr-2019-0066
Corresponding author: Nevena Draginic Department of Pharmacy, Faculty of Medical Sciences, University of Kragujevac, Serbia Svetozara Markovica 69, P.O.Box 124 34000 Kragujevac, Serbia Tel: + 381-34306 800 Fax: + 381-34 306800 


\section{INTRODUCTION}

Protective effects of creatine (Cr) in cardiovascular health have been investigated by multiple research groups. Since myocytes do not synthesize $\mathrm{Cr}$ physiologically, these cells depend on cellular uptake across the membrane by creatine transporter (CrT) to maintain intracellular Cr levels. Hypoxia interferes with energy metabolism, including the activity of the Cr energy shuttle, and therefore affects intracellular adenosine triphosphate (ATP) and phosphocreatine (PCr) levels. For example, profound alterations in $\mathrm{Cr}$ and $\mathrm{PCr}$ levels are observed in heart failure and in the peri-infarct region of the heart in animal models of ischemic injury. Recent study reports the benefits of $\mathrm{Cr}$ supplementation in the form of ability to enhance the physiological response to oxidative stress through the increase of ATP and PCr content in hypoxic (ischemic) cardiomyocites (1). Also, it was reported that an increase in cardiac $\mathrm{Cr}$ content exerted a protective effect in a rat model of ischemia and reperfusion (2). Additionally, it has been demonstrated that $\mathrm{Cr}$ supplementation ameliorates oxidative stress caused by doxorubicin in cultured cardiomyocytes (3).

Small amount of evidence about the effects of betaine and GAA (guanidinoacetic acid) supplementation on cardiovascular system is available, especially in humans. So far, some authors revealed the possible antiangiogenic effect of betaine via suppression of ROS (reactive oxygen species) mediated VEGF (vascular endothelial growth factor) signaling in mice model. This effect might be helpful in reduction of ische$\mathrm{mia} /$ reperfusion injury by the reduction of oxidative stress (4). Others, show that betaine protects against coagulation events in vivo and in vitro and suggest that betaine pretreatment decreases lipid peroxidation in plasma $(5,6)$. As for the animal models, several mechanisms of betaine cardioprotective effects were described in the literature, from antiatherosclerotic, antioxidant, membrane stabilizing properties to decrease in accumulated long-chain acylcarnitines in the period of myocardial ischemia (7-12).

There is no doubt that $\mathrm{Cr}$ and related compounds have the potential to act cardioprotective. Therefore, the aim of this review article is to systematically represent and obtain the results of the studies that have investigated the effects of $\mathrm{Cr}$ and $\mathrm{Cr}$ related compounds (GAA and betaine) supplementation on cardiovascular system and possible role of oxidative stress.

\section{Metabolism of creatine}

In the human organism the main $\mathrm{Cr}$ storage is present in skeletal muscle (two-thirds in a phosphorylated form and one-third as free $\mathrm{Cr}$ ) where their concentrations are approximately about $30 \mathrm{mM}$, while lower, but not less important concentration can be found in brain, about $10 \mathrm{mM}$. Two crucial physiological roles of $\mathrm{Cr}$ refer to muscle mass development and urine removal in the form of creatinine. There are two ways to maintain the right amount of $\mathrm{Cr}$ in the body, adequate nutritional intake and endogenous synthesis (13).
Endogenous synthesis of $\mathrm{Cr}$ is approximately 1 gram per day and occurs extensively in the liver and kidneys, to a lesser extent in the pancreas. The rest of $\mathrm{Cr}$ is consumed by diet and is synthetized from two essential amino acids arginine and methionine and one nonessential amino acid glycine (14). Three enzymes take part in this process: The first enzyme Larginine:glycine amidinotransferase (AGAT), mostly in the kidney, transfers the amidino group from arginine to glycine to yield L-ornithine and guanidinoacetic acid (GAA). The second one, methionine adenosyltransferase (MAT) converts methionine into S-adenosylmethionine (SAM) where SAM acts as donor of methyl group for GAA at the original glycine nitrogen and by action of the third enzyme N-guanidinoacetate methyltransferase (GAMT), predominantly in the liver, yields $\mathrm{Cr}$ and S-adenosylhomocysteine (SAH) (Figure 1) (15-17). AGAT is found in the kidney and GAMT in the liver, that implies an interorgan movement of GAA from the kidney to the liver. So, Cr biosynthesis is an inter-organ process.

Figure 1. Creatine metabolism

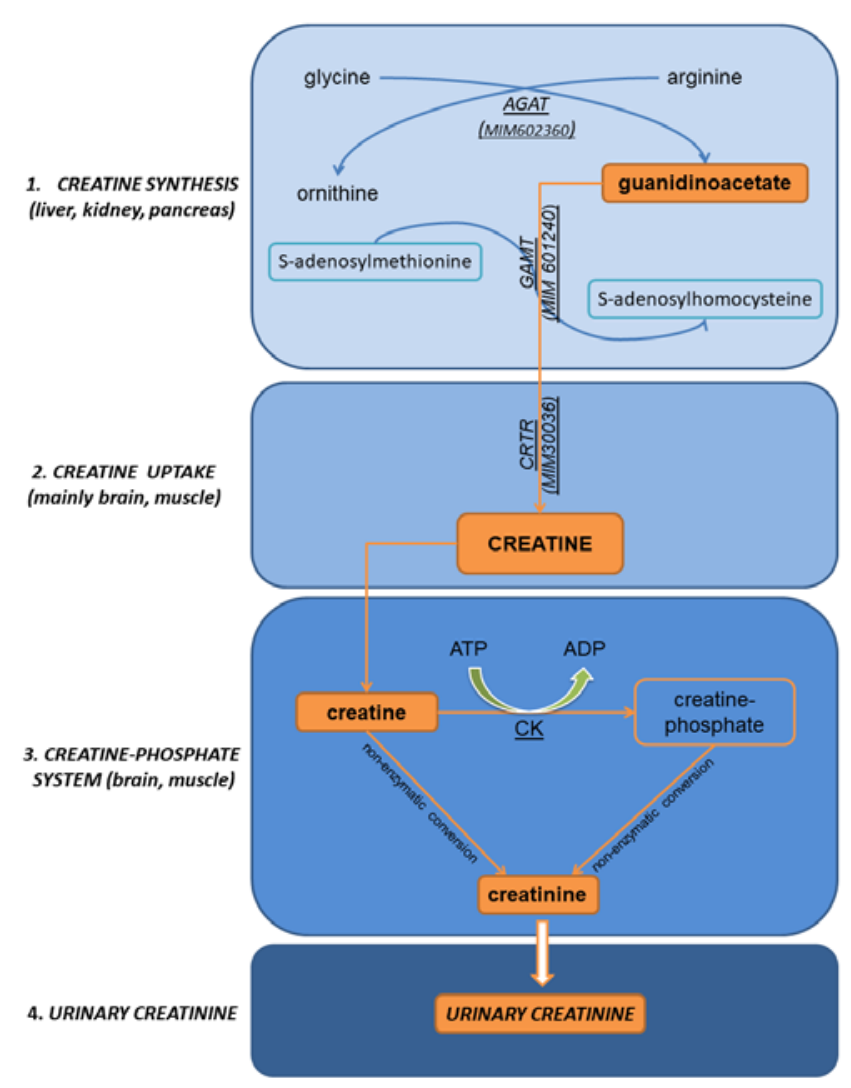

AGAT-L-arginine:glycine amidinotransferase; GAMTguanidinoacetate N-methyltransferase; CRTR - creatine transporter; CK- creatine kinase; ADP-adenosinediphosphate; ATP-adenosine-triphosphate

The role of $\mathrm{Cr}$ transporter (CrT; gene family transporters SLC6A8) is inevitable because that is the only known mechanism for $\mathrm{Cr}$ uptake through the plasma membrane. This transporter is similar and closely related to $\gamma$-aminobutyrate 
(GABA), taurine and betaine transporters and is highly specific for Cr. Given in notice the physiological role of $\mathrm{Cr}$ it is clear that CrT is expressed in the tissues that demand energy, such as skeletal muscle, heart, kidney and brain. Cardiomyocytes also take up Cr from the bloodstream via plasma membrane CrT. Afterwards phosphoryl group from ATP is being transferred to $\mathrm{Cr}$ in order to form phosphocreatine (PCr). This reaction happens in the mitochondria and is catalysed by mitochondrial creatine-kinase (Mt-CK) which is located in the intermembrane space of mitochondria and results with increasing level of PCr in cytosol, where it serves as a highly mobile, short-term energy reserve. The reverse reaction results in formation of ATP and is catalysed by the cytosolic CK dimers closely coupled to ATPases. Creatine uptake (against a 50-fold concentration gradient) depends of the trans-membrane $\mathrm{Na}^{+}$gradient and includes co-transport of two $\mathrm{Na}^{+}$and one $\mathrm{Cl}^{-}$for each molecule of $\mathrm{Cr}(6,15,16)$. In other words, CrT is a symporter that uses the energy accumulated in the sodium gradient across the membrane to induce the transport of Cr into the cell. During the transport cycle, a $\mathrm{Cl}^{-}$ion is also translocated into the cell with a stoichiometry of $2 \mathrm{Na}^{+}: 1 \mathrm{Cl}^{-}: 1 \mathrm{Cr}$. In cardiac and skeletal myocytes, Cr uptake depends of extracellular $\mathrm{Cr}$ concentration: increases in extracellular $\mathrm{Cr}$ content decrease $\mathrm{Cr}$ uptake, contrary, decreases in $\mathrm{Cr}$ content increase $\mathrm{Cr}$ uptake. Thus, the homeostasis of intracellular $\mathrm{Cr}$ content is physiologically regulated by negative feedback (7) Cr cell efflux includes two parallel processes, low level of passive $\mathrm{Cr}$ efflux and diffusion of non-enzymatic creatine degradation products $(6,12)$.

Due to the fact that cardiomyocytes do not normally express AGAT and GAMT proteins it is considered that local Cr biosynthesis in not thought to occur in the heart tissue but there is evidence about the expression of AGAT mRNA in the heart under pathological conditions, whose importance needs to be furtherly explained without concomitant expression of GAMT $(6,8,9)$. Some authors have investigated the sex differences in the metabolism and suggested that the effectiveness of $\mathrm{Cr}$ as an ergogenic aid for female athletes is less than that for men. This variability probably is the consequence of the cyclic nature of female sex hormones, and/or the presence or absence of testosterone. It is well established the sex difference in creatinine clearance by Cockroft and Gault and serum Cr values, which are higher in females (10, 11), afterwards Brosnan et al. subjected that daily Cr synthesis is higher in males than females (17), while recent study conducted in 2015. exposed the fact that concentration of circulating GAA is higher in males (18).

\section{Creatine as a supplement}

Large and still growing number of studies and research groups have been investigating the efficacy of $\mathrm{Cr}$ supplementation. Beneficial effects of Cr were firstly shown in sport, among athletes, where itself has been recognized as an ergogenic substance, increasing exercise tolerance, muscle strength and lean body mass $(2,19,20)$. Clinically viewed, Cr supplementation is very interesting, due to the fact that Cr supplementation have been reported to be beneficial for wide spectar of diesases and conditions reffering neurodegenerative, rheumatic diseases, myopathies, cancer, type 2 diabetes. In spite of widespread investigation of $\mathrm{Cr}$, its safety profile has remained excellent $(21,22)$. It is of great importance to emphasize the differences between $\mathrm{Cr}$ supplementation effect in middle aged/old people and young athletes that are commonly used in studies regarding beneficial effects of Cr. Several authors confirmed the efficacy of $\mathrm{Cr}$ supplementation in older population regarding increased lean and/or body mass and muscle function. What is more, this positive effect is present in both acute and chronic Cr supplementation and in conjunction with resistance training, which could result in even greater skeletal muscle adaptation than just performing resistance training (23-25). Yet, others` findings are different, suggesting Cr supplementation doesn`t augment the adaptive effects of resistance training combined with whey protein on muscle function and body composition in older individuals (26).

Cr might also be helpful in bone diseases since $\mathrm{PCr}$ is used to resynthesize energy (ATP) in bone cells. In other words it may stimulate osteoblast, or inhibit osteoclast and reduce bone resorption. Nevertheless, this promising bone protective potential has to be furtherly examined, since, the data from the studies are inconsistent. There is evidence about the positive effects of 24-week treatment with Cr combined with resistance training on muscle function, but not bone mass and bone serum markers and fat mass in population of older women (27). In aging adults, Cr supplementation ( $7 \mathrm{~g} / \mathrm{d}$ ) may have beneficial effects on bone mineral density if combined with more frequent ( $\geq 3$ days/week) resistance training for long period (a year or more). Studies of Cr supplementation in humans of shorter durations or using lower doses showed no benefit on bone properties $(28,29)$.

Another energy demanding tissue is certainly neuronal, thus it can also benefit from Cr supplementation. Large number of studies has investigated the neuroprotective effects of $\mathrm{Cr}$ in different diseases, from neurodegenerative to cognitive disorders. This includes inborn or acquired diseases characterized by progressive loss of nervous-system cells such as Alzheimer's, Huntington's, Charcot-Marie-Tooth's and Parkinson's disease and amyotrophic lateral sclerosis (ALS) which all have in common characteristics, such as energy depletion in brain, increased oxidative stress and dysfunction of mitochondria. Cr administration in these conditions might alleviate mentioned dysfunctions (30-32).

High increase in muscle Cr content caused by Cr supplementation can be expected in individuals with lower muscular Cr content (for example, vegetarians). Nevertheless, this increase in Cr content varies from 0 to $40 \%$ and can be achieved by loading phase (high dose/short term or low dose/long term) and subsequently remained constant by maintenance phase (2-3g/d) (33). Over the last few decades several forms of $\mathrm{Cr}$ have been synthetized in order to exhibit improved physical performance, better chemical properties, increased bioavailability, improved effectiveness and safety profile. The most commonly used among Cr supplements 
are: creatine-pyruvate, creatine-citrate, creatine-malate, creatine-taurinate, creatine-phosphate, creatine-orotate, creatine-ethylester, creatine-pyroglutamate, creatine-gluconate, and magnesium-creatine chelate (21). Two dosing schemes of $\mathrm{Cr}$ are commonly found in the literature: short term/ high dose protocol ( $20 \mathrm{~g} / \mathrm{d}$ or $0,3 \mathrm{~g} / \mathrm{kg} / \mathrm{d}$ for 5 days respectively) and long term/low dose protocol ( $3 \mathrm{~g} / \mathrm{d}$ or $0.03 \mathrm{~g} / \mathrm{kg} / \mathrm{d}$ for about 4-6 weeks) $(34,35)$. If properly dosed, most of these $\mathrm{Cr}$ forms, were not reported to have safety concerns. Possible concerns reffer to magnesium $\mathrm{Cr}$-chelate which could manifest gastrointestinal adverse effects when the tolerable upper intake level of the supplementary magnesium intake (250$350 \mathrm{mg}$ ) is exceeded, creatine ethyl ester which can be related to increase in serum creatinine levels, due to high gastrointestinal conversion of creatine ethyl ester to creatinine, creatine-phospate could induce mild gastrointestinal symptoms if supplemented more the $750 \mathrm{mg}$ phosphorus daily, while the tricreatine-orotate form was related to significant safety issues due to tumor-promoting effects of orotic acid $(14,36-$ 39). Up until today, the safety of creatine supplementation has remained unknown in children and adolescents.

\section{Guanidinoacetic acid (GAA) as a precursor of creatine}

As previously mentioned, guanidinoacetic acid (GAA also known as glycocyamine or guanidinoacetate) is a natural precursor of Cr, playing an important role as an energy carrier/mediator in the cell. GAA together with L-ornithine is formed in the first step of creatine synthesis in an enzymecatalyzed (AGAT) reaction from two amino acids L-arginine and glycine, mostly in the kidney and pancreas, while second step happens in the liver and requires GAMT enzyme (13, $16,17)$. Step one reaction in the Cr synthesis was discovered to be rate-limiting because of the fact that respective AGAT enzyme is subject to feedback inhibition on a pretranslational stage (40), while Cr control by feedback for enzyme GAMT wasn`t observed (41).

Up until now it is well known that exogenous application of Cr can increase and help filling up the cellular levels of $\mathrm{Cr}$ in the conditions such as physical activity, ageing, neurodegenerative, neuromuscular and cardiovascular disease, but data that speak about GAA as a supplement and its power and safety profile are inconsistent and unclear $(12-14,19)$. Supplementation with GAA might be of great significance in some circumstances where biosynthesis of GAA is limited like deficient diet, kidney failure, renal insufficiency, exercise-related GAA depletion (41). There are many advantages of GAA as a supplement: higher solubility in water, bioavailability, stability and cost-effectiveness in comparison with $\mathrm{Cr}$ $(16,42)$. Nowadays, GAA oral supplementation is a novel concept and strategy to increase cellular Cr levels in different conditions.

Several studies evaluated the metabolic, clinical and therapeutic effect of GAA in the last decade. Ostojic et al. evaluated the effects of chronical six-week oral supplementation with 2,4 g of GAA daily in healthy humans, and suggested that GAA supplementation leads to a significant increase in fasting serum Cr, up to 50\% after six-week period with acceptable safety profile and low incidence of biochemical abnormalities, such as increased homocysteine level which can be omitted by promoting the removal mechanisms $(43,44)$. Same research group conducted more investigations relative to GAA, and also confirmed that even low doses $(1,2 \mathrm{~g} / \mathrm{d})$ induce significant improvement in exercise performance in young individuals of both genders (45). The pharmacokinetic profile after per os application of GAA was also investigated and it is confirmed that single dose of GAA pharmacokinetic parameters were nonlinear relative to dose size, and even higher dose of 4,8g induced longer time of absorption, augmented bioequivalence and longer half elimination time, thus, that GAA is subject to saturable metabolism (46). Back in 1950-s studies in humans discovered favorable effects of oral administration of GAA in patients with cardiac decompensation, arthritis, anxiety and depression (47-49). In addition, beneficial effects of GAA as a supplement was also confirmed in broilers where GAA showed increase in growth and feed conversion ratio (47). Several authors observed moderate hyperhomocysteinemia after GAA oral supplementation in rat animal model, while others discovered antioxidant system disturbances after intrastriatal application of GAA $(20,50,51)$. What is more, oral supplementation with GAA has recently shown significant increase in $\mathrm{Cr}$ in the brain and nervous tissue, which is of great importance in neurodegenerative and neuromuscular diseases (52).

\section{Betaine as a new ergogenic compound}

Betaine (N-trimethylglycine) is a neutral compound in the form of zwitter ion, that can be found in the human body either as the product of oxidation of choline in the liver or kidneys or by nutrition. High content of betaine can be found in foods such as vegetables, such as wheat bran, wheat germ, wheat bread, spinach, beets, sugar beets and in seafood such as shrimp and shellfish (53). Two crucial physiological roles of betaine have been described, as a methyl donor in the transmethylation of homocysteine and as an osmolyte maintaining fluid balance. Catabolism of betaine happens in the kidney and liver, exactly in mitochondria, and involves a couple of reactions that result in the transmethylation of homocystein to methionine, catalyzed by betaine homocysteine S-methyltransferase (BHMT), and the subsequent formation of di-methylglycine (DMG). In this way, betaine conserves Met for protein synthesis, detoxifies homocystein, and supplies the universal methyl donor S-adenosylmethionine (SAM). Its metabolism connects several metabolites that play an important role in the health of humans, including choline (an important source of betaine), and homocysteine and methionine which are involved in its catabolism $(54,55)$.

Betaine as a supplement, has received attention recently because of the number of studies associating betaine supplementation with improved cognition, neuroprotection, cardioprotection and exercise physiology (56-65). Speaking of the impact of betaine on nervous system, variable studies have investigated this topic and the potential neuroprotection by betaine (63-65). Knight et al. indicate hippocampal 
accumulation of betaine(via betaine/GABA transporter (BGT1)), which is time dependent, dose dependent and osmolality dependent and also observe the effect on other osmolytes and neurotransmission which reflects in reduction of taurine, $\mathrm{Cr}$ and myoinositol in isosmotic conditions and dramatic change in glutamate an glycine in hyperosmotic state. All of this implicate neuromodulation in the hipocampal region that is particularily succeptible to damage and possible neuroprotection (63). Others evaluated positive betaine effect in cognitive and memory disorders such as Alzheimer`s disease $(64,65)$. A cohort study conducted in patients with acute coronary event, such as acute myocardial infarction, heart failure failure and secondary acute myocardial infarction examined connection between betaine insufficiency and secondary events in these patient and has come to conclusion that betaine insufficiency represents increased risk for secondary heart failure and acute myocardial infarction, high level of plasma homocysteine appears to be associated with evidence of betaine insufficiency, and the subjects with both high homocysteine and possible betaine insufficiency are at greater risk of secondary events, especially heart failure and also that increased plasma level of betaine might be connected with metabolic syndrome and diabetes (66). Mechanism of action of betaine as an ergogenic substance was investigated by several authors $(57,58,67)$. Bloomer and his research team reported that nor acute or chronic supplementation with betaine did not impact plasma nitrate/nitrite in exercise-trained men, contradictory to Iqbal et al. results (66, 67). Pryor and his coworkers came to similar results, reffering that acute application of betaine does not increase plasma nitrate levels nor alter cardiovascular response at rest or during light to moderate cycling (68).

\section{Effects of creatine, betaine and GAA on cardiovascular system}

It is already clear and explained in the literature why the role of $\mathrm{Cr}$ in energetic metabolism is of great importance. This refers to buffering and transfer of chemical energy in the form of ATP via the CK catalysed reactions and connection between the energy production and energy utilization in the cell in accordance with high energy demand $(3,15)$. There is a wealth of evidence that many components of the CK system are impaired in chronic heart failure and that there exists a tight connection between a low PCr/ATP ratio and mortality in human heart failure. A possible strategy of reversing this energetic deficit is strongly supported by recent findings that $\mathrm{M}-\mathrm{CK}$ overexpression protects against heart failure in a mouse pressure-overload model $(3,69)$.

Many studies have investigated the possible antioxidant activity of $\mathrm{Cr}$ because of its well established role in the energetic metabolism in the cell. What is more, functional importance of this is reflected in pathophysiology of myocardial ischemia/reperfusion injury and should contribute to cardioprotective effect of $\mathrm{Cr}$ in this condition. The animal model that is often used for this type of investigation enrolls mice with elevated $\mathrm{Cr}$ due to over-expression of the creatine transporter (CrT-OE) and mice with creatine-deficiency (GAMT
KO) and comparison between these two group of animals. Such investigation has been done by Aksentijevic et al., where the authors suggest that $\mathrm{Cr}$ content does not influence the detrimental effects of acute oxidative stress on cardiac function or in other words that $\mathrm{Cr}$ doesn `t seem to exercise antioxidant activity on the isolated heart using Langendorff model (70).

On the other side, Cr overexpression in CrT-OE hearts seems to protect from the ischemic-reperfusion injury in vivo in a dose-dependent way (increase of myocardial Cr 20$100 \%)$, while greater functional recovery ex vivo. This can be explained by increase in energy storage in the form of $\mathrm{PCr}$ and delay of mitochondrial permeability transition pore opening (mPTP) induced in oxidative stress during both ischemic and reperfusion injury, but no antioxidant effect was confirmed in this study since creatine did not attenuate the response to $\mathrm{H}_{2} \mathrm{O}_{2}$, in spite of earlier reported antioxidant activity of $\mathrm{Cr}(3,71,72)$. In addition, Kingsley et al. also supported these findings since their study`s results did not discover Cr related enhancement of antioxidant defence or protection against lipid peroxidation induced by cycling in healthy males (73). Nevertheless, except antioxidant activity as a potential mechanism of protection, which is discussed in several studies, it was also shown that physiological Cr supplementation could express antiapoptic property and decrease in citotoxicity of cardiomyocites caused by doxorubicin (71). Some research group hypothesised that mice with AGAT enzyme deficiency fed with Cr free diet would create a whole body $\mathrm{Cr}$ deficiency and thus, cardiac impairment that could be improved by Cr supplementation. However, Cr was shown only to improve systolic pressure, while homoarginine supplementation completely preserved and recovered all other haemodynamic parameters in Langendorff perfused heart model (74). The reduced availability of $\mathrm{Cr}$ has been associated with HF, increased prevalence of ventricular arrhythmias and ischemia. Some researchers aimed to prove benefits of $\mathrm{Cr}$ supplementation in these patients. Even though several positive effects of Cr supplementation have been described mostly in healthy individuals, studies using $\mathrm{Cr}$ in patients with HF are reduced. The results of the present study show that intake of oral Cr supplements, at a dose that is proven to be effective in stimulating the beneficial effects of exercise training in younger healthy subjects, is safe but does not enhance the benefits of cardiac rehabilitation in patients with coronary artery disease or chronic heart failure (75).

Regarding GAA, not sufficient evidence is present to support its possible cardioprotective properties. Pioneer investigations relative to this topic were conducted back in the 1950-s, where the authors found that Cr precursor GAA exerts beneficial effects on patients in cardiac decompensation, when orally administered. Speculated mechanisms for this action were due to increase in energy levels or increased bioavailability of dimethylglycine for incorporation into tissues proteins, thus, possibly repairing damaged muscle cells of the heart $(33,34)$. Nevertheless, this research direction was left until the last decade. Recent human study focused on 
determining the effect of orally administered GAA on redox status of healthy men. Of all measured parameters: plasma total antioxidant capacity, superoxide dismutase (SOD), glutathione peroxidase, total oxidant status and malondialdehyde, only SOD activity significantly increased after 2-week of GAA (3g/day) administration suggesting possible antioxidant power of the GAA supplementation. Since SOD is an important element of enzymatic antioxidant defense system and strong superoxide scavenger, GAA treatment could be considered beneficial, since oxidative stress is present in many cardiovascular pathologies (76). Same research group additionally investigated the effect of same dosage of GAA administration on cardiometabolic and inflammation markers in healthy men. They observed no significant effects on traditional biomarkers of cardiometabolic risk. Both serum hsCRP (c-reactive protein) and insulin remained unchanged after 10-week GAA administration. Additionally ratio of triglycerides to HDL (high density lipoprotein) cholesterol, which is an indicator of atherogenic profile also remained unaffected by the GAA supplementation. This indicates that there is no major cardiometabolic impairment caused by GAA (77).

Previously mentioned cohort study conducted in patients with acute coronary event, such as acute myocardial infarction, heart failure and secondary acute myocardial infarction examined connection between betaine insufficiency and secondary events in these patient and has come to conclusion that betaine insufficiency represents increased risk for secondary heart failure and acute myocardial infarction, high level of plasma homocysteine appears to be associated with evidence of betaine insufficiency, and the subjects with both high homocysteine and possible betaine insufficiency are at greater risk of secondary events, especially heart failure and also that increased plasma level of betaine might be connected with metabolic syndrome and diabetes (66). Taking into consideration that betaine supplementation is not expensive and is safe, this strategy may be utilized in order to improve lipid profile of these patients, since betaine was proved to improve atherogenic profile in a mouse model. Given the fact that MTHR (methylentetrahydrofolate reductase) deficient mice are prone to lipid accumulation in aorta and liver and increased oxidative stress, betaine supplementation may be considered beneficial in these conditions. Long term supplementation with betaine was shown to reduce the risk for atherogenesis via decrease in cumulation of both homocysteine and lipids, in increasing ApoA-I levels, but with no effect on oxidative stress as measured by the levels of nitrosylated protein (78). Lipotropic effect of betaine could be explained with the possibility of betaine to promote transmethylation reactions which affect gene expression or provide the methyl groups that serve for phosphatidylcholine synthesis. Another publication confirmed these results in a different experimental model. It has been observed that chronic 14 week supplementation with 1,2 or $4 \%$ betaine resulted in decrease of atherosclerotic lesion area, reduction in aortic expression of TNF- $\alpha$ in a dose dependent manner in apolipoprotein E-deficient mice (46).

\section{CONCLUSION}

This mini-review outlines the evidence in support of creatine and creatine related compounds (GAA and betaine) elevation and examines the pharmacological approaches that are currently available. Since data from the available studies, regarding cardioprotection are inconsistent, this review might help clarifying the benefits of $\mathrm{Cr}$, GAA and betaine supplementation on cardiovascular system.

Table 1. Proposed mechanisms of cardiovascular effects of creatine, betaine and GAA

\begin{tabular}{|l|c|c|c|c|l|}
\hline \multicolumn{1}{|c|}{ Study } & Supplement & Dose/time & Effect on CVS & Mechanism & \multicolumn{1}{|c|}{ Sample } \\
\hline $\begin{array}{l}\text { Santacruz et al. Crea- } \\
\text { tine supplementation } \\
\text { reduces doxorubicin- } \\
\text { induced cardiomyo- } \\
\text { cellular injury. (2015) }\end{array}$ & Creatine & $5 \mathrm{mmol} / \mathrm{l}$ & $\begin{array}{c}\downarrow \text { function (pro- } \\
\text { tective) } \\
\text { stress } \\
\downarrow \text { citotoxicity } \\
\text { caused by } \\
\text { DOX. } \\
\downarrow \text { apoptosis } \\
\text { caused by } \\
\text { DOX }\end{array}$ & $\begin{array}{l}\text { Animal/ HL-1 cell } \\
\text { line/ Sprague Daw- } \\
\text { ley rats }\end{array}$ & \\
\hline $\begin{array}{l}\text { Mert et al. .Effects } \\
\text { of creatine supplemen- } \\
\text { tation on cardiac auto- } \\
\text { nomic functions in } \\
\text { bodybuilders.(2017) }\end{array}$ & $\begin{array}{c}\text { Creatine-mon- } \\
\text { ohydrate }\end{array}$ & $\begin{array}{c}\text { 7,5mg/day } \\
\text { 7,5eeks }\end{array}$ & $\begin{array}{c}\uparrow \text { elevated para- } \\
\text { sympathetic } \\
\text { modulation in } \\
\text { exercise }\end{array}$ & $\begin{array}{c}\text { Shift from va- } \\
\text { gal to sympa- } \\
\text { thetic cardiac } \\
\text { modulation }\end{array}$ & $\begin{array}{l}\text { Human/male body- } \\
\text { builders }\end{array}$ \\
\hline
\end{tabular}




\begin{tabular}{|c|c|c|c|c|c|}
\hline Study & Supplement & Dose/time & Effect on CVS & Mechanism & Sample \\
\hline $\begin{array}{l}\text { Kingsley et al. Role of } \\
\text { creatine supplementa- } \\
\text { tion on exercise-in- } \\
\text { duced cardiovascular } \\
\text { function and oxidative } \\
\text { stress.(2009) }\end{array}$ & Creatine & $\begin{array}{l}20 \text { g/day } \\
5 \text { days }\end{array}$ & $\begin{array}{c}\text { No enhance in } \\
\text { non-enzymatic } \\
\text { antioxidant de- } \\
\text { fence or protect } \\
\text { against lipid } \\
\text { peroxidation }\end{array}$ & - & $\begin{array}{l}\text { Human/ males ex- } \\
\text { hausting cycling } \\
\text { exercised }\end{array}$ \\
\hline $\begin{array}{l}\text { Santacruz et al. Hy- } \\
\text { poxia decreases crea- } \\
\text { tine uptake in cardio- } \\
\text { myocytes, while crea- } \\
\text { tine supplementation } \\
\text { enhances HIF activa- } \\
\text { tion. (2017). }\end{array}$ & Creatine & $1 \mathrm{mmol} / \mathrm{l}$ & $\uparrow \mathrm{HIF}$ activation & $\begin{array}{c}\uparrow A T P \\
\uparrow P C r \text { in hy- } \\
\text { poxic RNCS }\end{array}$ & $\begin{array}{l}\text { Animal/ Rat neona- } \\
\text { tal cardiomyocites } \\
\text { (RNCS cell line) }\end{array}$ \\
\hline $\begin{array}{l}\text { Carvalho et al. Influ- } \\
\text { ence of creatine supple- } \\
\text { mentation on the func- } \\
\text { tional capacity of pa- } \\
\text { tients with heart fail- } \\
\text { ure. (2012) }\end{array}$ & Creatine & $\begin{array}{c}5 \mathrm{~g} / \mathrm{d} \\
6 \text { months }\end{array}$ & $\begin{array}{l}\text { No significant } \\
\text { improvement }\end{array}$ & I & $\begin{array}{l}\text { Male patients with } \\
\text { heart failure }\end{array}$ \\
\hline $\begin{array}{l}\text { Hemati et al.Effects of } \\
\text { Complementary Crea- } \\
\text { tine Monohydrate and } \\
\text { Physical Training on } \\
\text { Inflammatory and En- } \\
\text { dothelial Dysfunction } \\
\text { Markers Among Heart } \\
\text { Failure Patients. (2016) }\end{array}$ & $\begin{array}{l}\text { Creatine mon- } \\
\text { ohydrate }\end{array}$ & $\begin{array}{c}5 g / d \\
8 \text { weeks }\end{array}$ & $\begin{array}{c}\downarrow \text { IL-6 } \\
\downarrow \text { hsCRP } \\
\downarrow \text { VCAM1 } \\
\downarrow \text { p selectine }\end{array}$ & $\begin{array}{l}\text { Attenuation of } \\
\text { inflammation } \\
\text { and endothe- } \\
\text { lial dysfunc- } \\
\text { tion markers }\end{array}$ & $\begin{array}{l}\text { Patients with heart } \\
\text { failure (HF) }\end{array}$ \\
\hline $\begin{array}{l}\text { Cornelissen et al. } \\
\text { Effect of creatine sup- } \\
\text { plementation as a po- } \\
\text { tential adjuvant therapy } \\
\text { to exercise training in } \\
\text { cardiac patients: a ran- } \\
\text { domized controlled } \\
\text { trial.(2010) }\end{array}$ & $\begin{array}{c}\text { Creatine mon- } \\
\text { ohydrate } \\
+ \\
\text { Combined aer- } \\
\text { obic and re- } \\
\text { sistance train- } \\
\text { ing(3/week) }\end{array}$ & $\begin{array}{c}5 \mathrm{~g} / \mathrm{d} \\
3 \text { months }\end{array}$ & $\begin{array}{l}\text { No significant } \\
\text { improvement } \\
\text { in cardiac reha- } \\
\text { bilitation }\end{array}$ & I & $\begin{array}{l}\text { Female patients } \\
\text { with coronary arter- } \\
\text { ies disease and } \\
\text { chronic heart fail- } \\
\text { ure }\end{array}$ \\
\hline $\begin{array}{l}\text { Lygate et al. Moderate } \\
\text { elevation of intracellu- } \\
\text { lar creatine by targeting } \\
\text { the creatine transporter } \\
\text { protects mice from } \\
\text { acute myocardial in- } \\
\text { farction. (2012) }\end{array}$ & I & I & $\begin{array}{l}\downarrow \text { ischemia- } \\
\text { reperfusion in- } \\
\text { jury }\end{array}$ & $\begin{array}{c}\downarrow \mathrm{mPTP} \\
\uparrow \text { energy re- } \\
\text { serve(PCr) }\end{array}$ & CrT-OE mice \\
\hline $\begin{array}{l}\text { Faller, et al. Impaired } \\
\text { cardiac contractile } \\
\text { function in argi- } \\
\text { nine:glycine amidi- } \\
\text { notransferase knockout } \\
\text { mice devoid of creatine } \\
\text { is rescued by } \\
\text { homoarginine but not } \\
\text { creatine.(2018) }\end{array}$ & $\begin{array}{l}\text { standard diet } \\
\text { with } 0.5 \% \\
\text { (w/w) crea- } \\
\text { tine l- } \\
\text { Homoarginine } \\
\text { hydrochloride }\end{array}$ & $\begin{array}{c}1 \text { and } 7 \\
\text { weeks } \\
\begin{array}{c}14 \mathrm{mg} / \mathrm{l} 10 \\
\text { days }\end{array}\end{array}$ & $\begin{array}{l}\text { No significant } \\
\text { effect on heart } \\
\text { functional re- } \\
\text { coverry }\end{array}$ & $\begin{array}{l}\uparrow \mathrm{LV} \text { end-sys- } \\
\text { tolic pressure } \\
\uparrow \mathrm{LV} \text { end dias- } \\
\text { tolic pressure } \\
\text { No effect on } \\
\text { other func- } \\
\text { tional parame- } \\
\text { ters }\end{array}$ & AGAT-/- mice \\
\hline
\end{tabular}




\begin{tabular}{|c|c|c|c|c|c|}
\hline Study & Supplement & Dose/time & Effect on CVS & Mechanism & Sample \\
\hline $\begin{array}{l}\text { Ostojic, et al. Oxidant- } \\
\text { Antioxidant Capacity } \\
\text { of Dietary } \\
\text { Guanidinoacetic Acid } \\
\text { (2015) }\end{array}$ & $\begin{array}{l}\text { Guanidinoace- } \\
\text { tic acid }\end{array}$ & $\begin{array}{l}2 \text { weeks } \\
3 g / \text { day }\end{array}$ & $\begin{array}{c}\text { Potential } \downarrow \text { oxi- } \\
\text { dative stress }\end{array}$ & Mild $\uparrow S O D$ & Healthy men \\
\hline $\begin{array}{l}\text { Ostojic, et al. Effects of } \\
\text { Guanidinoacetic Acid } \\
\text { Loading } \\
\text { on Biomarkers of Car- } \\
\text { diometabolic } \\
\text { Risk and Inflammation } \\
\text { (2018) }\end{array}$ & $\begin{array}{l}\text { Guanidinoace- } \\
\text { tic acid }\end{array}$ & $\begin{array}{l}10 \text { weeks } \\
\text { 3g/day }\end{array}$ & $\begin{array}{l}\text { No significant } \\
\text { changes in car- } \\
\text { diometabolic } \\
\text { markers (HDL, } \\
\text { TGL, CK, } \\
\text { CRP,AST, } \\
\text { ALT, GGT) }\end{array}$ & / & $\begin{array}{l}\text { Healthy men and } \\
\text { women }\end{array}$ \\
\hline $\begin{array}{l}\text { Schwahn, et al. Betaine } \\
\text { supplementation im- } \\
\text { proves the atherogenic } \\
\text { risk factor profile in a } \\
\text { transgenic mouse } \\
\text { model of hyperhomo- } \\
\text { cysteinemia (2007) }\end{array}$ & betaine & $\begin{array}{c}1 \text { year } \\
300 \mathrm{mg} / \mathrm{kg}\end{array}$ & $\begin{array}{c}\downarrow \text { TGL } \\
\uparrow \text { HDL choles- } \\
\text { terol } \\
\text { No effect on } \\
\text { oxidative stress }\end{array}$ & $\begin{array}{c}\text { Improvement } \\
\text { od atherogenic } \\
\text { profle }\end{array}$ & $\begin{array}{l}\text { MTHFR deficient } \\
\text { mice }\end{array}$ \\
\hline $\begin{array}{l}\text { Lv S, et al. Betaine } \\
\text { supplementation atten- } \\
\text { uates atherosclerotic le- } \\
\text { sion in apolipoprotein } \\
\text { E-deficient mice } \\
\text { (2009) }\end{array}$ & betaine & $\begin{array}{c}14 \text { weeks } \\
0,1,2 \text { or } 4 \mathrm{~g} \\
\text { of beat- } \\
\text { ine } 100 \mathrm{~g} \text { diet }\end{array}$ & $\begin{array}{l}\downarrow \text { aortic expres- } \\
\text { sion of TNF- } \\
\text { alpha in a dose- } \\
\text { dependent way }\end{array}$ & $\begin{array}{l}\text { Inhibition of } \\
\text { aortic inflam- } \\
\text { matory re- } \\
\text { sponse medi- } \\
\text { ated by TNF- } \\
\text { alpha. } \\
\end{array}$ & $\begin{array}{l}\text { APO-E deficient } \\
\text { mice }\end{array}$ \\
\hline
\end{tabular}

\section{REFERENCES}

1. Kalhan SC, Gruca L, Marczewski S, Bennett C. Whole body creatine and protein kinetics in healthy men and women: effects of creatine and amino acid supplementation. Amino acids 2015; 1-11.

2. Santacruz L, Arciniegas AJL, Darrabie M, Mantilla JG, Baron RM, Bowles DE, et al. Hypoxia decreases creatine uptake in cardiomyocytes, while creatine supplementation enhances HIF activation. Physiol Rep 2017; 5(16). pii: e13382.

3. Lygate CA., Bohl S, ten Hove M, Faller KM, Ostrowski PJ, Zervou S, et al. Moderate elevation of intracellular creatine by targeting the creatine transporter protects mice from acute myocardial infarction. Cardiovasc. Res 2012; 96: 466-75.

4. Maresh CM, Farrell MJ, Kraemer WJ, Yamamoto LM, Lee EC, Armstrong LE, et al. The effects of betaine supplementation on strength and power performance. Med Sci Sports Exerc 2008; 39:S101.

5. del Favero S, Roschel H, Artioli G, Ugrinowitsch C, Tricoli V, Costa A, et al. Creatine but not betaine supplementation increases muscle phosphorylcreatine content and strength performance. Amino Acids 2012; 42(6): 2299-305.

6. Speer O, Neukomm LJ, Murphy RM, Zanolla E, Schlattner $U$, Henry $H$, et al. Creatine transporters: a reappraisal. Mol. Cell. Biochem 2004; 256-257(1-2): 407-24.

7. Lygate CA., Bohl S, ten Hove M, Faller KM, Ostrowski PJ, Zervou S, et al. Moderate elevation of intracellular creatine by targeting the creatine transporter protects mice from acute myocardial infarction. Cardiovasc. Res 2012; 96: 466-75.

8. Skelton MR, Schaefer TL, Graham DL, Degrauw TJ, Clark JF, Williams MT, et al. Creatine Transporter (CrT; Slc6a8) Knockout Mice as a Model of Human CrT Deficiency. PLoS One 2011; 6(1):e16187 .

9. Cullen ME, Yuen AH, Felkin LE, Smolenski RT, Hall JL, Grindle S, et al. Myocardial expression of the arginine:glycine amidinotransferase gene is elevated in heart failure and normalized after recovery: potential implications for local creatine synthesis. Circulation 2006; 114(1) Suppl.:I16-I20.

10. Cockcroft DW, Gault MH. Prediction of creatinine clearance from serum creatinine. Nephron 1976; 16: 3141.

11. Delanghe J, de Slypere J, de Buyzere M, Robbrecht J, Wieme R, Vermeulen A . Normal reference values for creatine, creatinine, and carnitine are lower in vegetarians. Clin Chem 1989; 35: 1802-3. 
12. Brosnan J, Brosnan M. Creatine: endogenous metabolite, dietary, and therapeutic supplement. Annu Rev Nutr 2007; 27: 241-61.

13. Joncquel-Chevalier Curt M, Voicu PM, Fontaine M, Dessein AF, Porchet N, Mention-Mulliez K, et al. Creatine biosynthesis and transport in health and disease. Biochimie 2015; 119: 146-65.

14. Butts J, Jacobs B, Silvis M. Creatine Use in Sports. Sports Health 2018; 10(1): 31-4.

15. Zervou S, Whittington HJ, Russell JA, Lygate CA. Augmentation of Creatine in the Heart Mini Rev Med Chem. 2016; 16(1): 19-28.

16. Wyss M., Kaddurah-Daouk R. Creatine and creatinine metabolism. Physiol Rev 2000; 80(3): 1107-213.

17. Brosnan J.T., da Silva R.P., Brosnan M.E. The metabolic burden of creatine synthesis. Amino Acids 2011; 40(5): 1325-31.

18. Kalhan SC, Gruca L, Marczewski S, Bennett C. Whole body creatine and protein kinetics in healthy men and women: effects of creatine and amino acid supplementation. Amino acids 2015; $1-11$.

19. Poortmans, JR, Rawson ES, Burke LM, Stear SJ. et al.A$\mathrm{Z}$ of nutritional supplements:dietary supplements, sports nutrition foods and ergogenic aids for health and performance Part 11. Br. J. Sports Med 2010; 44: 765-6.

20. Fukada S, Setoue M, Morita T. et al. Dietary eritadenine suppresses guanidinoacetic acid-induced hyperhomocysteinemia in rats. J Nutr 2006; 136: 2797-802.

21. Andres S, Ziegenhagen R, Trefflich I, Pevny S, Schultrich $\mathrm{K}$, Braun $\mathrm{H}$, et al. Creatine and creatine forms intended for sports nutrition. Mol Nutr \& Food Res. 2017; 61(6): 1600772.

22. Gualano B, Roschel H, Lancha AH Jr, Brightbill CE, Rawson ES. In sickness and in health: the widespread application of creatine supplementation. Amino Acids 2012; 43(2): 519-29.

23. Gualano B, Rawson ES, Candow DG, Chilibeck PD. Creatine supplementation in the aging population: effects on skeletal muscle, bone and brain. Amino Acids 2016; 48(8): 1793-805.

24. Neves M Jr, Gualano B, Roschel H, Fuller R, Benatti FB, Pinto AL, et al. Beneficial effect of creatine supplementation in knee osteoarthritis. Med Sci Sports Exerc 2011; 43: 1538-43.

25. Wilkinson TJ, Lemmey AB, Jones JG, Sheikh F, Ahmad YA, Chitale S, et al. Can creatine supplementation improve body composition and objective physical function in rheumatoid arthritis patients? A randomised controlled trial. Arthritis Care Res (Hoboken) 2016; 68(6): 729-37.

26. Collins J, Longhurst G, Roschel H, Gualano B. Resistance Training and Co-supplementation with Creatine and Protein in Older Subjects with Frailty. J Frailty Aging 2016; 5(2): 126-34.

27. Gualano B, Macedo AR, Alves CR, Roschel H, Benatti FB, Takayama L, et al. Creatine supplementation and resistance training in vulnerable older women: a randomized double-blind placebo-controlled clinical trial. Exp Gerontol 2014; 53:7-15.
28. Chilibeck PD, Candow DG, Landeryou T, Kaviani M, Paus-Jenssen L. Effects of creatine and resistance training on bone health in postmenopausal women. Med Sci Sports Exerc 2015; 47(8): 1587-95.

29. Chrusch MJ, Chilibeck PD, Chad KE, Davison KS, Burke DG. Creatine supplementation combined with resistance training in older men. Med Sci Sports Exerc 2001; 33(12): 2111-7.

30. Andres RH, Ducray AD, Schlattner U, Wallimann T, Widmer HR. Functions and effects of creatine in the central nervous system. Brain Res Bull 2008; 76(4): 32943.

31. Amital D, Vishne T, Roitman S, Kotler M, Levine J. Open study of creatine monohydrate in treatment-resistant posttraumatic stress disorder. J Clin Psychiatry 2006; 67(5): 836-7.

32. Amital D, Vishne T, Rubinow A, Levine J. Observed effects of creatine monohydrate in a patient with depression and fibromyalgia. Am J Psychiatry 2006; 163(10): 1840-1.

33. Buford TW, Kreider RB, Stout JR, Greenwood M, et al., International Society of Sports Nutrition position stand: creatine supplementation and exercise. J Int Soc Sports Nutr 2007; 4: 1-8.

34. Harris RC, Soderlund K, Hultman E. Elevation of creatine in resting and exercised muscle of normal subjects by creatine supplementation. Clin Sci (Lond) 1992; 83(3): 367-74.

35. Hultman E, Soderlund K, Timmons JA, Cederblad G, Greenhaff PL. Muscle creatine loading in men. J Appl Physiol 1996; 81(1): 232-7.

36. EFSA, (European Food Safety Authority), Orotic acid salts as sources of orotic acid and various minerals added for nutritional purposes to food supplements, scientific opinion of the panel on food additives and nutrient sources added to food (ANS). EFSA J. 2009; 1187: 125.

37. Velema, M. S., de Ronde, W., Elevated plasma creatinine due to creatine ethyl ester use. Neth J Med 2011; 69: 79-81.

38. EFSA, (European Food Safety Authority), Statement of EFSA: assessment of one published review on health risks associated with phosphate additives in food. EFSA J. 2013, 11, 3444.

39. EFSA, (European Food Safety Authority), Tolerable upper intake levels for vitamins and minerals 2006.

40. Edison EE, Brosnan ME, Meyer C, Brosnan JT. Creatine synthesis: production of guanidinoacetate by the rat and human kidney in vivo. Am J Physiol Renal Physiol 2007; 293: F1799-804.

41. Walker JB. Creatine: biosynthesis, regulation, function. Adv Enzymol Relat Areas Mol Biol 1979; 50: 177-242.

42. Ostojic SM, Vojvodic-Ostojic A. Single-dose oral guanidinoacetic acid exhibits dose-dependent pharmacokinetics in healthy volunteers. Nutrition Research 2015; 35(3): 198-205.

43. Ostojic SM, Niess B, Stojanovic M, Obrenovic M. Creatine Metabolism and Safety Profiles after Six-Week 
Oral Guanidinoacetic Acid Administration in Healthy Humans. Int J Med Sci 2013; 10(2): 141-7.

44. Ostojic SM, Niess B, Stojanovic M, Obrenovic M. Coadministration of methyl donors along with guanidinoacetic acid reduces the incidence of hyperhomocysteinaemia compared with guanidinoacetic acid administration alone. Br J Nutr 2013; 14; 110(5): 865-70.

45. Ostojic SM, Stojanovic MD, Hoffman JR. Six-Week Oral Guanidinoacetic Acid Administration Improves Muscular Performance in Healthy Volunteers. J Investig Med 2015; 63(8): 942-6.

46. Ostojic SM, Vojvodic-Ostojic A. Single-dose oral guanidinoacetic acid exhibits dose-dependent pharmacokinetics in healthy volunteers. Nutr Res, 2015; 35(3): 198205.

47. Michiels J, Maertens L, Buyse J. et al. Supplementation of guanidinoacetic acid to broiler diets: effects on performance, carcass characteristics, meat quality, and energy metabolism. Poult Sci 2012; 91: 402-12.

48. Borsook ME, Borsook H. Treatment of cardiac decompensation with betaine and glycocyamine. Ann West Med Surg 1951; 5: 830-55.

49. Graybiel A, Patterson CA. Use of betaine and glycocyamine in the treatment of patients with heart disease: preliminary report. Ann West Med Surg 1951; 5: 863-75.

50. Stead LM, Au KP, Jacobs RL. et al. Methylation demand and homocysteine metabolism: effects of dietary provision of creatine and guanidinoacetate. Am J Physiol Endocrinol Metab 2001; 281: E1095-100.

51. Zugno AI, Stefanello FM, Scherer EB. et al. Guanidinoacetate decreases antioxidant defenses and total protein sulfhydryl content in striatum of rats. Neurochem Res 2008; 33: 1804-10.

52. Ostojic SM, Ostojic J, Drid P, Vranes M, Jovanov P. Dietary guanidinoacetic acid increases brain creatine levels in healthy men. Nutrition 2017; 33: 149-56.

53. Zeisel SH, Mar M-H, Howe JC, Holden JM. Concentrations of choline-containing compounds and betaine in common foods. J Nutr 2003; 133: 1302-7.

54. Williams KT, Schalinske KL. New insights into the regulation of methyl group and homocysteine metabolism. J Nutr 2007; 137: 311-4.

55. Cholewa JM, Guimarães-Ferreira L, Zanchi NE. Effects of betaine on performance and body composition: a review of recent findings and potential mechanisms. Amino Acids 2014; 46(8), 1785-93.

56. Lv S, Fan R, Du Y, Hou M, Tang Z, Ling W, et al. Betaine supplementation attenuates atherosclerotic lesion in apolipoprotein E-deficient mice. Eur J Nutr 2009; 48(4): 205-12.

57. Lee EC, Maresh CM, Kraemer WJ, Yamamoto LM, Hatfield DL, Bailey BL, et al. Ergogenic ef fects of betaine supplementation on strength and power performance. J Int Soc Sports Nutr 2010; 7:27.

58. Hoffman JR, Ratamess NA, Kang J, Rashti SL, Faigenbaum AD .Effect of betaine supplementation on power performance and fatigue. J Int Soc Sports Nutr 2009; 6:7.

59. Maresh CM, Farrell MJ, Kraemer WJ, Yamamoto LM, Lee EC, Armstrong LE, et al. The effects of betaine supplementation on strength and power performance. Med Sci Sports Exerc 2008; 39:S101.

60. Ganesan B, Buddhan S, Anandan R, Sivakumar R, AnbinEzhilan R. Antioxidant defense of betaine against isoprenaline-induced myocardial infarction in rats. Mol Biol Rep 2010; 37(3): 1319-27.

61. Ganesan B, Anandan R. Protective effect of betaine on changes in the levels of lysosomal enzyme activities in heart tissue in isoprenaline-induced myocardial infarction in Wistar rats. Cell Stress Chaperones 2009; 14(6): 661-7.

62. Ganesan B, Buddhan S, Jeyakumar R, Anandan R. Protective effect of betaine on changes in the levels of membrane-bound ATPase activity and mineral status in experimentally induced myocardial infarction in Wistar rats. Biol Trace Elem Res 2009; 131(3): 278-90.

63. Knight LS, Piibe Q, Lambie I, Perkins C, Yancey PH. Betaine in the Brain: Characterization of Betaine Uptake, its Influence on Other Osmolytes and its Potential Role in Neuroprotection from Osmotic Stress. Neurochem Res 2017; 42(12): 3490-503.

64. Zabrodina VV, Shreder OV, Shreder ED, Durnev AD. Effect of afobazole and betaine on cognitive disorders in the offspring of rats with streptozotocin-induced diabetes and their relationship with DNA damage. Bull Exp Biol Med 2016; 161: 359-66.

65. Chai GS, Jiang X, Ni ZF, Ma ZW, Xie AJ, Cheng XS, et al. Betaine attenuates Alzheimer-like pathological changes and memory deficits induced by homocysteine. J Neurochem 2013; 124: 388-96.

66. Lever M, George PM, Elmslie JL, Atkinson W, Slow S, Molyneux SL,et al. Betaine and Secondary Events in an Acute Coronary Syndrome Cohort. PLoS One 2012; 7(5): e37883.

67. Iqbal O, Fareed D, Cunana J, Hoppensteadt D, Messadek J, Baltasar F, Fareed J. Betaine induced release of tissue factor pathway inhibitor and nitric oxide: implications in the management of cardiovascular disease. Presented at the 2006 meeting of Experimental Biology. 2006.

68. Bloomer RJ, Farney TM, Trepanowski JF, McCarthy CG, Canale RE. Effect of betaine supplementation on plasma nitrate/nitrite in exercise-trained men. J Int Soc Sports Nutr 2011; 8: 5.

69. Pryor JL, Wolf ST, Sforzo G, Swenesen T. The Effect of Betaine on Nitrate and Cardiovascular Response to Exercise. Int J Exerc Sci 2017; 10(4): 550-9.

70. Aksentijević D, Zervou S, Faller KME, McAndrew DJ,Schneider JE, Neubauer S, et al. Myocardial Creatine Levels Do Not Influence Response to Acute Oxidative Stress in Isolated Perfused Heart. PLoS One 2014; 9(10): e109021.

71. Santacruz L, Darrabie MD, Mantilla JG, Mishra R, Feger BJ, Jacobs DO. Creatine supplementation reduces doxorubicin-induced cardiomyocellular injury. Cardiovasc Toxicol 2015; 15: 180-8.

72. Lawler JM, Barnes WS, Wu G, Song W, Demaree S. Direct antioxidant properties of creatine. Biochem Biophys Res Commun 2002; 290: 47-52. 
73. Kingsley MIC, Cunningham D, Mason L, Kilduff LP, McEneny J. Role of creatine supplementation on exercise-induced cardiovascular function and oxidative stress. Oxid Med Cell Longev 2009; 2(4): 247-54.

74. Faller KME, Atzler D, McAndrew DJ, Zervou S, Whittington HJ, Simon JN, et al. Impaired cardiac contractile function in arginine:glycine amidinotransferase knockout mice devoid of creatine is rescued by homoarginine but not creatine. Cardiovasc Res 2018; 114(3): 417-30.

75. Cornelissen VA, Defoor JG, Stevens A, Schepers D, Hespel P, Decramer M, et al. Effect of creatine supplementation as a potential adjuvant therapy to exercise training in cardiac patients: a randomized controlled trial. Clin Rehabil 2010; 24(11): 988-99.

76. Ostojic SM, Stojanovic MD, Olcina G. Oxidant-Antioxidant Capacity of Dietary Guanidinoacetic Acid. Ann Nutr Metab 2015; 67(4): 243-46.

77. Ostojic SM, Trivic T, Drid P, Stajer V, Vranes M. Effects of Guanidinoacetic Acid Loading on Biomarkers of Cardiometabolic Risk and Inflammation. Ann Nutr Metab 2017; 72(1): 18-20.

78. Schwahn BC, Wang XL, Mikael LG, Wu Q, Cohn J, Jiang H,et al. Betaine supplementation improves the atherogenic risk factor profile in a transgenic mouse model of hyperhomocysteinemia. Atherosclerosis 2007;195(2):e100-7.

79. HR, Musani SK, Dibaba DT, Talegawkar SA, Taylor HA, Tucker KL, et al. Dietary choline and betaine; associations with subclinical markers of cardiovascular disease risk and incidence of CVD, coronary heart disease and stroke: the Jackson Heart Study. Eur J Nutr 2018; 57(1): 51-60. 